\title{
Coagulation Studies in Severe Birth Asphyxia
}

\author{
J. M. CHESSELLS^ and J. S. WIGGLESWORTH \\ From the Departments of Haematology and Child Health, Hammersmith Hospital
}

\begin{abstract}
Chessells, J. M., and Wigglesworth, J. S. (1971). Archives of Disease in Childhood, 46, 253. Coagulation studies in severe birth asphyxia. Coagulation studies have been performed in 9 infants who were so severely asphyxiated at birth as to require assisted ventilation for at least 10 minutes. Four of the infants died, though none suffered from any bleeding tendency in life. In 2 fatal cases and 1 survivor the laboratory findings of circulating fibrin degradation products, low plasma fibrinogen, and low or rising platelet count indicated that disseminated intravascular coagulation had occurred in the first few hours of life. Fibrin thromboemboli were found in the liver and adrenals of the 2 such babies that died.

One baby had a low level of vitamin $\mathrm{K}$ dependent factors associated with fetal growth retardation.

Clinical factors common to the cases with evidence of disseminated intravascular coagulation were the need for mechanical ventilation, and the occurrence of hypothermia.

Though haemostatic failure due to disseminated intravascular coagulation is likely to develop only in a small minority of birth asphyxiated infants, the possibility should be considered in any that become hypothermic within a few hours of birth.
\end{abstract}

There have been a number of case reports of haemostatic failure in infants with severe birth asphyxia. Valentine (1958) and Reerink-Brongers and De Koningh (1964) reported low plasma fibrinogen levels in these infants and a similar case has been reported more recently by Skyberg and Jacobsen (1969).

In theory, asphyxia could influence haemostasis in the newborn in one of two ways: either by promoting consumption of platelets and coagulation factors as a consequence of disseminated intravascular coagulation, thus resulting in a fall in platelet count, fibrinogen, factors V and VIII, and the formation of fibrin degradation products, or, by causing an exaggerated fall in the level of vitamin $\mathrm{K}$ dependent factors II, VII, IX, and X. A further possibility is that conditions with a high risk of birth asphyxia (e.g. fetal growth retardation) might also be associated with coagulation defects.

Hathaway and Henderson (1968) investigated this problem in newborn puppies and concluded that asphyxia depressed the level of vitamin $\mathrm{K}$ dependent factors, but they did not measure the

\footnotetext{
Received 16 December 1970.

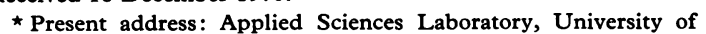
Sussex, Falmer, Brighton.
}

platelet count or plasma fibrinogen level. Hardaway et al. (1964) have suggested that a fall in $p H$ accelerates the clotting time and may tend to promote disseminated intravascular coagulation.

We have performed coagulation studies on a small group of babies who were severely asphyxiated at birth to find out if any haemostatic abnormality occurs regularly in such infants.

\section{Materials and Methods}

The infants studied were all admitted to the neonatal ward at the Hammersmith Hospital for supervision following severe birth asphyxia which had necessitated resuscitation with intubation and intermittent positive pressure ventilation. Samples of blood for study were aspirated from the umbilical cord before delivery of the placenta; follow-up samples were taken from an umbilical arterial catheter or from a peripheral vein.

Blood was taken into a 1 in 10 dilution of $\mathrm{Na}$ citrate with the addition of $1 / 10$ th volume of $10 \%$ epsilon amino caproic acid to those samples intended for estimation of plasma fibrinogen and fibrin degradation products (FDP). The following tests were performed, based on those described in Dacie and Lewis (1968): a platelet count, plasma fibrinogen, thrombin-fibrinogen time expressed as a ratio patient/adult normal, Thrombotest, and thromboplastin generation screening test. 
TABLE I

Clinical Data on Infants

\begin{tabular}{|c|c|c|c|c|c|c|c|}
\hline Case No. & Birthweight (g) & Gestation (wk) & Delivery & $\begin{array}{l}\text { Apgar } \\
\text { Score } \\
1 \mathrm{~min}\end{array}$ & $\begin{array}{c}\text { IPPR } \\
\text { Duration } \\
\text { (min) }\end{array}$ & $\begin{array}{c}\text { Minimum } \\
\text { Temperature } \\
\left({ }^{\circ} \mathbf{C}\right)\end{array}$ & Outcome \\
\hline $\begin{array}{l}1 \\
2 \\
3 \\
4 \\
5 \\
6 \\
7 \\
8 \\
9\end{array}$ & $\begin{array}{l}3300 \\
3100 \\
2540 \\
2600 \\
2000 \\
2240 \\
2560 \\
2000 \\
3250\end{array}$ & $\begin{array}{r}40 \\
40 \\
? 36 \\
40 \\
34 \\
38 \\
34 \\
34 \\
40\end{array}$ & $\begin{array}{c}\text { Forceps } \\
\text { LSCS } \\
\text { Vertex } \\
\text { LSCS } \\
\text { Vertex } \\
\text { LSCS } \\
\text { LSCS } \\
\text { Forceps } \\
\text { Breech }\end{array}$ & $\begin{array}{l}2 \\
1 \\
0 \\
1 \\
0 \\
0 \\
0 \\
0 \\
1\end{array}$ & $\begin{array}{c}10 \\
10 \\
30 \\
15 \\
\text { Ventilator } \\
19 \\
\text { Ventilator } \\
\text { Ventilator } \\
\text { Ventilator }\end{array}$ & $\begin{array}{l}36 \cdot 1 \\
36 \cdot 1 \\
35 \cdot 0 \\
36 \cdot 1 \\
33 \cdot 9 \\
32 \cdot 8 \\
34 \cdot 7 \\
33 \cdot 9 \\
30 \cdot 6\end{array}$ & $\begin{array}{c}\text { Lived } \\
\text { Lived } \\
\text { Lived } \\
\text { Lived } \\
\text { Lived } \\
\text { Died } 43 \mathrm{hr} \\
\text { Died } 4 \mathrm{dy} \\
\text { Died } 21 \mathrm{hr} \\
\text { Died } 30 \mathrm{hr}\end{array}$ \\
\hline
\end{tabular}

LSCS $=$ lower segment caesarean section.

FDP were measured on thrombin-treated plasma by the method of Merskey, Lalezari, and Johnson (1969). The methods used and the results obtained in normal infants are described in detail elsewhere (Chessells, 1971).

The postmortem material was stained with phosphotungstic acid haematoxylin and examined for the presence of fibrin thromboemboli.

\section{Results}

Clinical data on the 9 infants are presented in Table I. All infants required assisted ventilation; the length of time for which this was necessary is noted in the Table. Cases $5,7,8$, and 9 were unable to maintain spontaneous respirations. Case 1 responded to stimulation at birth; in
Cases 2, 4, and 9 the only sign of life was an apex beat; in the other 5 infants no apex beat was detectable at delivery. Body temperature was recorded on all infants on admission to the ward: in 4 it was under $34^{\circ} \mathrm{C}$. All the infants were fed with milk from the time of admission, and only one (Case 4) was given vitamin $K$. No infant in the series showed any clinical evidence of a bleeding tendency.

Laboratory results are given in Table II. In Cases 1-3 there was no detectable disturbance of haemostasis apart from the low thrombotest and prolongation of the thromboplastin generation screening test which reflect the reduced level of vitamin $\mathrm{K}$ dependent coagulation factors always present in the newborn infant. Case 4 was born

TABLE II

Laboratory Findings

\begin{tabular}{|c|c|c|c|c|c|c|c|}
\hline Case No. & Age (hr) & $\begin{array}{l}\text { Platelets } \\
\left(10^{3} / \mathrm{mm}^{3}\right)\end{array}$ & $\begin{array}{c}\text { Fibrinogen } \\
(\mathrm{mg} / 100 \mathrm{ml})\end{array}$ & FDP Titre & $\begin{array}{c}\text { Thrombin/ } \\
\text { Fibrinogen } \\
\text { Ratio }\end{array}$ & $\begin{array}{c}\text { Thrombotest } \\
(\%)\end{array}$ & TGST (sec)t \\
\hline $\begin{array}{l}1 \\
2 \\
3 \\
4 \\
5 \\
6 \\
7 \\
8 \\
9\end{array}$ & $\begin{array}{r}0^{\star} \\
24 \\
0 \\
24 \\
2 \\
0 \\
23 \\
2 \\
16 \\
72 \\
2 \\
18 \\
1 \\
24 \\
8 \\
18 \\
3 \\
10\end{array}$ & $\begin{array}{r}225 \\
246 \\
154 \\
171 \\
192 \\
250 \\
220 \\
167 \\
252 \\
238 \\
236 \\
258 \\
209 \\
219 \\
112 \\
335 \\
251\end{array}$ & $\begin{array}{r}151 \\
178 \\
141 \\
186 \\
173 \\
149 \\
198 \\
97 \\
125 \\
252 \\
112 \\
164 \\
100 \\
126 \\
-134 \\
21 \\
102\end{array}$ & $\begin{array}{r}0 \\
0 \\
0 \\
0 \\
0 \\
0 \\
0 \\
2 \\
0 \\
0 \\
0 \\
0 \\
0 \\
0 \\
4 \\
2 \\
64 \\
16\end{array}$ & $\begin{array}{r}1 \cdot 4 \\
1 \cdot 6 \\
1 \cdot 4 \\
\overline{1.5} \\
1 \cdot 4 \\
\overline{1.6} \\
\overline{-} \\
\overline{1 \cdot 9} \\
\overline{1.8} \\
\overline{1.5} \\
\overline{1.3} \\
\overline{2 \cdot 6}\end{array}$ & $\begin{array}{r}17 \\
21 \\
26 \\
23 \\
16 \\
9 \\
34 \\
20 \\
- \\
20 \\
20 \\
22 \\
11 \\
26 \\
26\end{array}$ & $\begin{array}{r}12 \\
13 \\
16 \\
11 \\
15 \\
30 \\
9 \\
- \\
- \\
\frac{15}{15} \\
\frac{19}{12} \\
\frac{11}{11}\end{array}$ \\
\hline Normal infant & Day 1 & $168-378$ & $123-280$ & 0 & $1-2$ & $16-50$ & $8-25$ \\
\hline
\end{tabular}

$\star$ Age 0 = cord blood sample.

† TGST $=$ thromboplastin generation screening test. 
TABLE III

Necropsy Findings

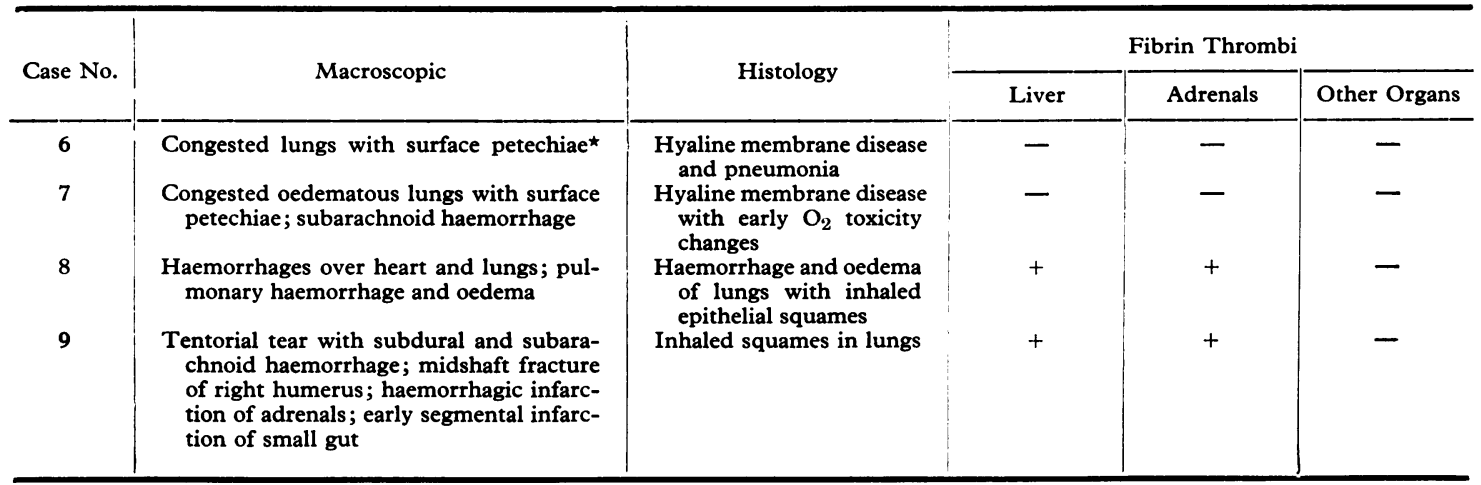

* Lungs stable on pressure-volume determination.

at term but was small for dates weighing only 2600 g. The cord blood showed a very low thrombotest $9 \%$ and thromboplastin generation screening test $(30 \mathrm{sec})$, and the infant was given $1 \mathrm{mg}$ vitamin $\mathrm{K}$. At 23 hours the Thrombotest had risen to $34 \%$ and the thromboplastin generation screening test was $9 \mathrm{sec}$.

Case 5, a premature infant, remained on the ventilator for 5 days. Her initial coagulation studies revealed a low plasma fibrinogen level $(97 \mathrm{mg} / 100 \mathrm{ml})$ and FDP in serum diluted 1 in 2; at follow-up no FDP were detected and the plasma fibrinogen had risen to $125 \mathrm{mg} / 100 \mathrm{ml}$; the platelet count rose to a maximum of $478 \times 10^{3} / \mathrm{mm}^{3}$ by day 6 .

Cases 6 and 7 showed low normal initial plasma fibrinogen levels (112 and $100 \mathrm{mg} / 100 \mathrm{ml}$ ), but normal platelet counts and screening tests for coagulation factors, and no FDP were detected. In Case 8 a low platelet count $\left(112 \times 10^{3} / \mathrm{mm}^{3}\right)$ was accompanied by the presence of FDP to a maximum titre of serum diluted 1 in 4 . Case 9, an undiagnosed breech, was profoundly hypothermic on admission and had a very low plasma fibrinogen level $(21 \mathrm{mg} / 100 \mathrm{ml})$ with FDP in high titre ( 1 in 64) and an increased thrombin ratio $(2 \cdot 6)$. The initial platelet count of $335 \times 10^{3} / \mathrm{mm}^{3}$ had fallen to $251 \times 10^{3} / \mathrm{mm}^{3}$ by the age of 10 hours but the Thrombotest and thromboplastin generation screening test were not grossly abnormal.

Necropsy findings on the 4 infants who died are detailed in Table III. The lesions were compatible with severe asphyxia and Case 9 had a tentorial tear and fractured humerus resulting from birth trauma. Intravascular fibrin thrombi were found in the liver and adrenals in Cases 8 and 9.

\section{Discussion}

In this series of 9 babies who suffered severe birth asphyxia necessitating positive pressure ventilation for at least 10 minutes there was laboratory evidence of disordered haemostasis in 4, of whom 2 died, but none showed a clincally detectable bleeding tendency. If this series is typical of birth asphyxiated babies in general, haemostatic failure is unlikely to be a problem in the majority of such cases.

In 3 of the babies with abnormal laboratory findings (Cases 5,8 , and 9), there was evidence that a disturbance of haemostasis had occurred as a consequence of disseminated intravascular coagulation. Fibrin degradation products were detected in all 3 infants and were present with low plasma fibrinogen levels in 2 , and in association with mild thrombocytopenia or a sharply rising platelet count in one case each. Confirmation of this diagnosis was provided by the presence of fibrin thromboemboli in the sinusoids of liver and adrenals at necropsy in the 2 babies who died. In all 3 infants the maximum disturbance was present in the first few hours of life. As platelet counts in these infants were always above $100 \times 10^{3} / \mathrm{mm}^{3}$ they would not be expected to show any bleeding tendency.

One small-for-dates infant (Case 4) had a low level of vitamin $\mathrm{K}$ dependent factors at birth, which was corrected by administration of the vitamin. In no case was there evidence of a postnatal drop in vitamin $\mathrm{K}$ dependent factors. The policy of early feeding of asphyxiated infants is probably responsible for maintaining the levels (Gellis and Lyon, 1941). The single low level mentioned above may well be related to the baby being small 
for dates rather than to birth asphyxia, as we do have evidence of low levels of vitamin $\mathrm{K}$ dependent factors in small-for-dates infants.

Our studies indicate that disseminated intravascular coagulation is the most frequent cause of haemostatic abnormality in the asphyxiated infant, and it seems worth looking for common clinical factors in the 3 cases where this had occurred.

All 3 infants were so severely asphyxiated as to require treatment on the mechanical ventilator, 2 of them died, and the third required artificial ventilation for 5 days. Only one other infant required mechanical ventilation. It seems that these infants must have been subjected to more severe hypoxia, and more prolonged acidosis than the rest of the group. Another factor common to the infants with evidence of disseminated intravascular coagulation was the occurrence of hypothermia; all 3 babies had a minimum temperature below $34{ }^{\circ} \mathrm{C}$. Only one other baby in the series had a similarly low temperature.

The combination of ventilator therapy and a body temperature below $34{ }^{\circ} \mathrm{C}$ was seen only in the 3 infants with disseminated intravascular coagulation.

We have previously pointed out the association of severe hypothermia with haemostatic failure in the newborn (Chessells and Wigglesworth, 1970).

If acidosis and hypothermia have a synergistic action in causing disseminated intravascular coagulation, the newborn baby with acidosis of any cause who becomes hypothermic may be at particular risk to this form of haemostatic failure. However, as birth asphyxia can impair a baby's ability to maintain its body temperature, the hypothermia in our babies is perhaps only a further measure of the severity of the asphyxial episode.

The precise mechanism by which coagulation is triggered off in these circumstances remains a matter for debate. Stagnation of blood in the peripheral circulation is a possible factor: Gaynor, Bouvier, and Spaet (1968) have suggested as an alternative that anoxic damage to small blood vessels may form a basis for intravascular fibrin deposition.
From the clinical point of view the most important measure available for prevention of disseminated intravascular coagulation may well be to keep newborn babies warm.

Haemostatic failure due to disseminated intravascular coagulation is most likely to be evident within the first few hours after birth, and the possibility should be considered in any sick or premature newborn infant who becomes hypothermic at that time.

We thank Dr. W. R. Pitney for his helpful advice, Professor J. P. M. Tizard for reading the manuscript, and the Sir William Coxon Fund and the Wellcome Trust for their support.

Dr. J. M. Chessells was in receipt of a M.R.C. Fellowship.

Correspondence to Dr. J. S. Wigglesworth, Department of Child Health, Hammersmith Hospital, Du Cane Road, London W.12.

\section{REFERENCES}

Chessells, J. M. (1971). The significance of fibrin degradation products in the blood of normal infants. Biology of the Neonate, 17, 219.

Chessells, J. M., and Wigglesworth, J. S. (1970). Secondary haemorrhagic disease of the newborn. Archives of Disease in Childhood, 45, 539.

Dacie, J. V., and Lewis, S. M. (1968). Practical Haematology, p. 256. Churchill, London.

Gaynor, E., Bouvier, C. A., and Spaet, T. H. (1968). Circulating endothelial cells in endotoxin-treated rabbits. Clinical Research, 16, 535.

Gellis, S. S., and Lyon, R. A. (1941). The influence of the diet of the newborn infant on the prothrombin index. Fournal of Pediatrics, 19, 495.

Hardaway, R. M., Elovitz, M. J., Brewster, W. R., Jr., and Houchin, D. N. (1964). Clotting time of heparinized blood. Archives of Surgery, 89, 701.

Hathaway, W. E., and Henderson, B. J. (1968). Effect of hypoxia on coagulation factors in the newborn dog. Biologia Neonatorum, 13, 26.

Merskey, C., Lalezari, P., and Johnson, A. J. (1969). A rapid, simple, sensitive method for measuring fibrinolytic split products in human serum. Proceedings of the Society for Experimental Biology and Medicine, 131, 871.

Reerink-Brongers, E. E., and de Koningh, M. J. (1964). Acute fibrinolysis in a newborn infant. Lancet, $1,985$.

Skyberg, D., and Jacobsen, C. D. (1969). Defibrination syndrome in a newborn and its treatment with exchange transfusion. Acta Paediatrica, 58, 83.

Valentine, G. H. (1958). Fibrinolytic disease in both mother and newborn. Obstetrics and Gynecology, 12, 462. 